10-1993

\title{
Developing Content Standards: Creating a Process for Change
}

University of Pennsylvania

Follow this and additional works at: https://repository.upenn.edu/cpre_policybriefs

Part of the Curriculum and Instruction Commons, Educational Leadership Commons, and the Education Policy Commons

\section{Recommended Citation}

University of Pennsylvania. (1993). Developing Content Standards: Creating a Process for Change. CPRE Policy Briefs.

Retrieved from https://repository.upenn.edu/cpre_policybriefs/67

This document was authored by the Consortium for Policy Research in Education, but no individual authors were identified.

View on the CPRE website.

This paper is posted at ScholarlyCommons. https://repository.upenn.edu/cpre_policybriefs/67

For more information, please contact repository@pobox.upenn.edu. 


\title{
Developing Content Standards: Creating a Process for Change
}

\author{
Abstract \\ Education leaders at every level of the system are developing standards to specify what students should \\ know and be able to do in key subject areas. Local and state groups, professional organizations, and \\ consortia of states and districts are constructing standards. This brief outlines some lessons suggested \\ by past and current efforts to develop ambitious standards. It draws on studies by CPRE researchers of \\ standards-setting processes in five states: Vermont, Kentucky, New York, California, and South Carolina; \\ and three national curriculum standards projects. \\ Disciplines \\ Curriculum and Instruction | Educational Leadership | Education Policy

\section{Comments} \\ This document was authored by the Consortium for Policy Research in Education, but no individual \\ authors were identified. \\ View on the CPRE website.
}




\section{Developing Content Standards: Creating a Process for Change}

Education leaders at every level of the system are developing standards to specify what students should know and be able to do in key subject areas. Local and state groups, professional organizations, and consortia of states and districts are constructing standards.

The current movement to develop challenging, ambitious expectations for student learning can be traced to the pathbreaking efforts of the National Council of Teachers of Mathematics (NCTM) and states like California in the mid-1980s. Now, 45 states are planning, developing, or implementing new curriculum frameworks (Pechman and LaGuarda 1993). Nearly every major subject-matter association is engaged in the process of defining standards. National projects, like the National Board for Professional Teaching Standards and the New Standards Project, see the development of standards as a key element of their missions. And Congress is considering proposals to extend standards-based reform to federal programs.

Defining leading-edge, "world class" standards is viewed by many as a critical component of coherent, systemic reform. But the form and purposes of specific standards are diverse. Many states plan to use standards as anchors for other state policies, including policies about curriculum materials, teacher professional development, and student assessment. Some are elaborating upon general standards in more detailed curriculum framework documents; others are using the terms "standards" and "curriculum frameworks" interchangeably and producing one set of content specifications.

The policy instruments emphasized also vary from effort to effort. For instance, the New Standards Project, a coalition of 18 states and five school districts, is focusing not on content specifications but on performance-based assessment. Content standards will be specified in the course of developing assessment standards.

Many questions are raised by the use of standards to promote improvement. Can they be used to enhance opportunity to learn? Will they improve teaching and learning? Will standards lead to higher performance by all students or will they produce new inequities? Will the standards be reinforced by the broader society, by colleges and employers, for example? Such questions are the subject of debate and discussion in schools, districts, and policy arenas throughout the United States. ${ }^{1}$

Aside from these issues, there is another crucial question-how are standards actually developed? One of the most cited failures of previous curriculumreform efforts was their neglect of process. This brief deals with an important challenge of standards-based reform: creating a process to develop standards.

'Good discussions of other complicated issues surrounding
student standards are found in Smith and O'Day 1991; O'Day
and Smith 1993; Darling-Hammond 1992; Porter 1992; Porter
1993; Cohen and Spillane 1993; Fuhrman and Massell 1992. 
The brief outlines some lessons suggested by past and current efforts to develop ambitious standards. It draws on studies by CPRE researchers of standardssetting processes in five states: Vermont, Kentucky, New York, California and South Carolina, and three national curriculum standards projects. The projects are NCTM's efforts to develop standards for math instruction and evaluation, the College Board's design of its Advanced Placement program, and the National Science Foundation's efforts of the 1950s and 1960s to reform science curricula (Massell 1993; Massell, Kirst, Kelley and Yee 1993).

\section{Consensus vs. Innovation?}

A critical component of nearly all current standards-setting efforts is a serious commitment to forging broad public as well as professional consensus. But the idea of establishing agreement on expectations for student learning is new for American schools (Cohen and Spillane 1993; Fuhrman 1993). Without historical models to follow, states, localities and national groups are experimenting with new structures and procedures to reach broad consensus. They are drawing participants from a cross-section of interested parties, including teachers, parents, students, administrators, university faculty, business and community leaders, and policymakers.

Educators today are keenly aware of the problems that result when goals of change are not widely shared (Carlson 1992). In emphasizing consensus, standards groups are trying to avoid the mistakes of past curricular reform projects that neglected the social and political realities of implementation (McLaughlin 1991; Elmore 1993).
Establishing a broad consensus, however, is often in tension with achieving leading-edge standards. As one participant in the NCTM effort said:

On the one hand, if these standards were to stand as the banners of the community, then they had to reflect shared values and commitments. On the other hand, if change was desired, then these standards had to do more than reflect current practice. New ideas were needed, ideas that departed from extant assumptions and practices. (Ball 1992, 2-3)

NCTM did, in fact, achieve a high degree of consensus around what many perceive to be leading-edge content standards. It embarked on an extensive consensus-building process which involved thousands of practitioners, academics and other professionals as well as members of the lay public in different stages of agenda-setting and capacity-building. While some disputes linger, the degree of acceptance NCTM has achieved is what other standard-setting groups aim to emulate.

Given the goal of achieving consensus while at the same time developing challenging and meaningful standards, the following points may inform the process.

A useful start to standardsetting efforts is to explore the nature of each subject-matter area under consideration.

Each field poses unique challenges to the problem of achieving consensus, and an understanding of the "terrain" of each area can help inform decisions about how to develop standards.

In many respects, current standards projects are operating in an environment with a remarkable level of agreement on the broad substance and direction of the reforms needed to create excellence. Across the subject-matter fields, for instance, there is a strong push for higher-order thinking and active models of learning; more interdisciplinary learning and understanding; more in-depth coverage of a core set of topics rather than wide, but superficial coverage of many topics; and more challenging content for all students.

But while consensus exists at this broad and general level, when it comes to more specific decisions, many professional and public disagreements arise. For example, disciplines differ in the extent to which subspecialties are discrete and the degree to which they can be readily linked.

In contrast to the field of mathematics, highly distinct and competitive subgroups exist within disciplines like science and social studies. All of the separate subgroups in science, like biology, physics, and chemistry, compete for resources and time in the limited school calendar. A common attitude is "the standards are okay as long as they represent more of what I teach." Debates over the actual content that should be included in science or social studies standards are more contentious than in fields like mathematics.

Disciplinary linkages to ethical, moral, religious, and social debates must also be considered. Defining content in fields such as the sciences and social studies is almost certain to ignite public and professional passions over religion, evolution, and multiculturalism. In New York, the conflict over multiculturalism in the social studies curriculum has pervaded the consensus-building process.

Careful research into the background of each subject area can help standards developers antici- 
pate the challenges, assure representation that crosses divisions within a field, and deal effectively with such issues when they arise.

Processes for setting standards involve several stages of agenda setting, development, and review intended to encourage professional and public participation.

Approaches to balancing representation differ significantly across various state and national efforts. Some place greater emphasis on grassroots involvement, some stress professional participation, and others rely on a blend of strategies at different stages of the process. Vermont's broad-based approach to standard setting (members of the public and teachers are involved in all stages of the process, and all teachers in the state receive draft copies of the standards for review) grows out of a long state tradition of citizen governance. The state education department sponsored a number of public focus forums across the state to generate standards for what students should know and be able to do.

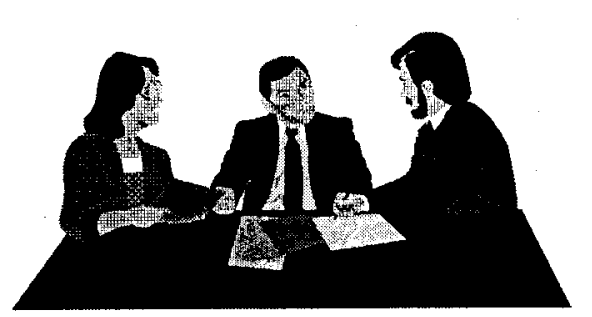

In contrast, California has emphasized the participation of leading educators to create cuttingedge frameworks, strongly based in research and expert opinion. As a result, the frameworks have gained widespread legitimacy among teachers. South Carolina looked closely at the California experience and also turned primarily to teams of professional leaders. But the state then circulated draft frameworks to large groups of both professionals and the lay public. After using a multifaceted process that included telephone surveys and consultations with large committees and citizen focus groups to identify goals, Kentucky used professional task forces to draft goals, learner outcomes, and curriculum frameworks.

Even the most broad-based, consultative processes can only reach a fraction of the citizens and a portion of the teachers and administrators who will ultimately use the standards to guide instruction. In the end, each school and district will have to develop its own versions or understandings of standards. Including the public and teachers in state or national efforts probably produces a better as well as a more legitimate framework, but it will not preclude local debates over implementation.

Standards development activities require reasonable time schedules.

One factor that seems to be a crucial precondition for developing consensus is time. One of the keys to NCTM's success was a slow, lengthy development process which took nearly a decade to complete. The association took plenty of time to educate the community about the need for standards, conduct research before the development committees met, and to solicit review and feedback.

Current reform efforts are operating in a more politically charged environment than existed when NCTM was deliberating. With the possibility that federal programs will require states to develop standards, and with state political leadership impatient for standards-based reforms to get underway, 10-year developmental processes are no longer practical. Despite the press for speed, however, allowing sufficient time for a broad review and feedback process is a critical component of any consensus-building strategy.

Standard setters are finding that different subject areas are not amenable to a single, rigid format.

While a common format may be desirable for some purposes, rigid formats may be unsuitable for different content areas.

Common formats might be useful for large issues that cross areas. For example, a state, association, or district might decide whether standards in each subject should address only what students should know and be able to do or also discuss assessment and teaching pedagogy. The intended purpose of a document is an important consideration which may lead to common design features. For instance, because one purpose of the California frameworks is to guide state-adopted textbook selection, each framework must contain a section stating adoption criteria.

However, the experiences of several groups suggest that the idiosyncracies of different subjectmatter areas may call for some differences in format. Assessment developers working on one of the National Board for Professional Teaching Standards' teams argued that the five propositions of good teaching which all the standardswriting groups were to follow squeezed out pedagogical and content logics unique to their own disciplines (Pence and Petrosky 1992).

California originally had an outline for all frameworks, but abandoned it when staff reported that it was too constricting. Thus formulaic requirements may thwart tailoring the structure, sequence, and design of the document to the unique pedagogical and substantive demands of the different discipline areas. 
Standards entities require mechanisms to "bridge" subject areas and ensure cross disciplinary discussion.

Coherence across the subjectmatter standards (not just within) is necessary to ensure that as a collective the standards are "doable" during the school day and year. Most of the National Science Foundation's 1950s and 1960s science curriculums did not take into consideration the competing demands and interests which fight for time and resources within a school. Additional time for science meant that time for other subjects had to be reduced, and science did not win out in the end.

Encouraging cross-disciplinary discussions during standard setting may improve the prospects for developing interdisciplinary teaching and learning. In addition, interdisciplinary efforts can be one way to avoid outpacing the capacity of schools and classrooms. For example, in the absence of crossdisciplinary approaches, elementary teachers will have to rapidly absorb new, distinct standards for each separate subject.

Some state standards efforts are doing much more than bridging the disciplines; they are trying to create learner outcomes that integrate and avoid distinctions among subjects. It is too early to assess the pros and cons of separate subject frameworks vs. integrated documents, but it is important to remember that teachers are accustomed to disciplinary distinctions and subjectbased curricula and may need special support to use integrated documents as guidance. As standards-setting efforts negotiate the continuum from free-standing, nonintegrated disciplinary frameworks, to more articulated/coordinated efforts, to frameworks with interdisciplinary themes and sections, to totally integrated sets of outcomes, they will have to decide whether to accept or to restructure traditional, disciplinary approaches to the organization of knowledge.

Decisions about the best level of detail and specificity are important components of standards-setting efforts.

The specificity issue raises many questions about the flexibility of the standards, their ability to lead, and their ability to provide substantial guidance to other policy components such as assessment. On the one hand, people argue that the standards should be broad enough to allow for many different curriculum designs and teaching approaches. On the other hand, broad standards are subject to multiple interpretations and may lose their potential to promote high quality and to anchor other policy efforts. For example, some have criticized the NCTM standards for lacking sufficient precision to guide assessment, program selection, or program evaluation. The balance between specificity and flexibility can be a difficult one to achieve, but standards efforts need not see these as either/or alternatives. For example, standards can provide the flexibility for school and teacher choice by designing alternative strands of relatively precise standards.

Standards efforts need mechanisms for dealing with controversy.

While careful research into the nature of the subject area can help development processes identify potential problem areas, it will not protect them from the lobbying of citizens and various interest groups when controversial issues inevitably arise.

The very nature of the standardsetting exercise, which requires making explicit decisions about which content objectives are to be included, invites debate. For example, efforts to promote outcomes-based education in dif- ferent states are being attacked by people who view both the content of the outcomes and the shift away from traditional input requirements like credit hours as a way of imposing values counter to their beliefs, or straying from the central purpose of schooling.

Many states' standards have identified not just academic outcomes, but also affective outcomes, such as Pennsylvania's goal that students shall "understand and appreciate others." The outcry over this and similar statements that seemed to focus more on values than academics was vociferous, and Pennsylvania subsequently backed away from some of its outcome statements.

Institutional mechanisms which buffer standard setting from the direct control of politics can help protect the integrity and leadership potential of the standards, as can strong leadership. NCTM, for example, set up a commission to oversee the standards writing groups, thus providing a forum for debate. In California the active leadership of the state superintendent helped to steer the process through many political battles.

Some level of controversy will be inevitable. Equating consensus with the absence of controversy can produce standards which use vague, open-ended language subject to multiple interpretations. Vague, agreeable standards are unlikely to change school teaching and learning. Similarly, standards committees in some of the highly fractured fields like science or social studies may be tempted to patch a consensus together by including every subdiscipline, and every demand, equally, in the final standards document. But this approach can result in a fragmented and incoherent curriculum which emphasizes breadth of coverage over depth of inquiry, a result which is certainly not "world class." 
Another approach to consensusbuilding is the strategy used to develop the College Board's Advanced Placement (AP) curriculum and examination system. To produce these documents, the College Board surveys participating colleges and universities to closely align the AP program with current college curricula. In this way the program reflects the actual, "average" curricula. However, the survey approach also restricts the level of innovation included in the content standards. In other words, by limiting itself to the curriculum that is, Advanced Placement courses do not often move the curricula to what it ought to be.

Standards-setting processes can be the initial step in continuing capacity-building efforts.

Because standards activities involve numerous educators and citizens, they build understanding and support for reform. But capacity building does not end once the standards are developed and adopted. NCTM's lengthy review and feedback process aimed at engaging the entire mathematics community and building familiarity with and giving legitimacy to the standards. The standards development process also indicated where continuing capacity building was most needed, such as, in the area of using calculators for computation.

In California, the framework development process has been followed by efforts to support curriculum development at the district level. The state department issues many publications to support curriculum development based on the frameworks, provides pamphlets for teachers on supplemental literature that supports the frameworks, issues booklets for parents, and develops model curriculum guides for grades 9-12.

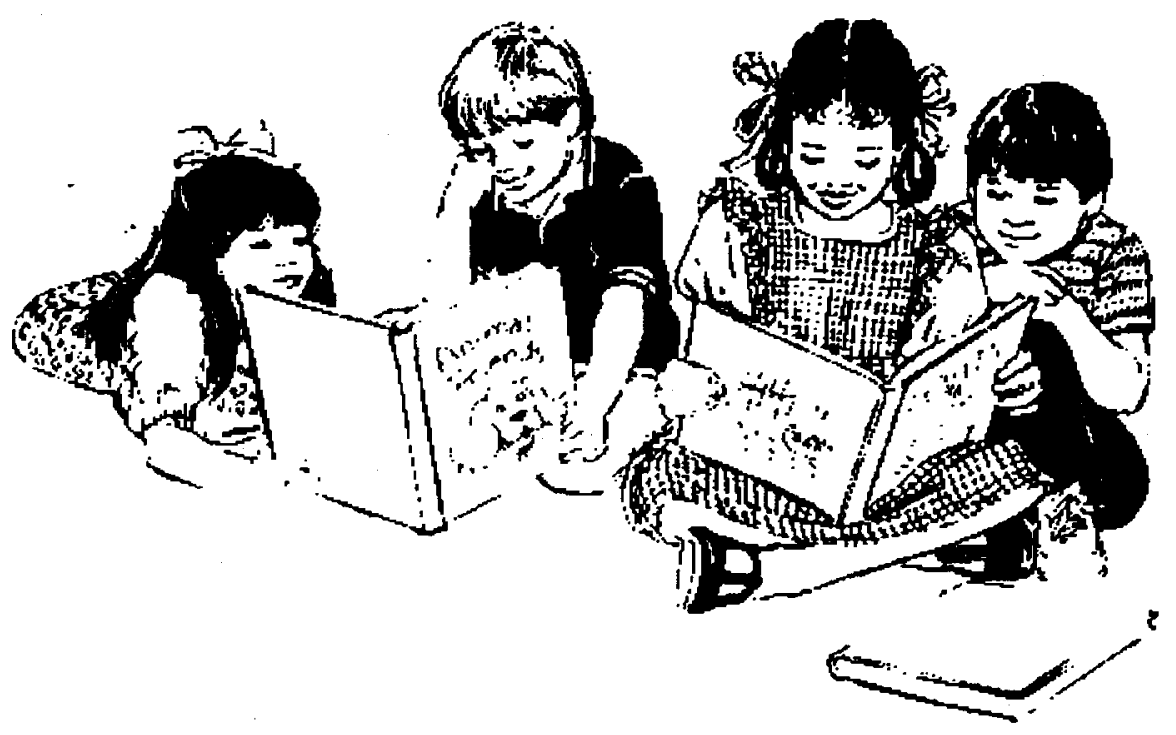

In contrast, many of the National Science Foundation efforts in the 1950 s and 1960 s saw educators as consumers of reform who needed retraining, rather than as partners in the curriculum reform effort. There was little connection with continuing staff development and leadership or with teacher education. Therefore, only a few teachers were prepared to use the new teaching methods required by the curriculums, and even where they were adopted, they were frequently taught in the "old" way.

Despite efforts of states like California to involve and assist teachers, investment in building capacity to support standards-based reform is sadly inadequate. The emerging standards call for farreaching changes in curriculum and instruction. However, most efforts to prepare teachers and administrators for the changes or to assure necessary technical assistance are small scale and temporary. Standards systems and processes can be helpful in alerting policymakers and the public to the need for long-term, substantial capacity building.

Standards will require revision over time.

One of the challenges confronting current standard-setting efforts is establishing a schedule for revision. While it may seem premature to contemplate changing newly minted standards, revision efforts will be needed lest current standards become calcified in policy and unresponsive to knowledge advances in the particular fields. The difficultly here is not only the human and financial resources involved in revisiting the efforts. The fact is that revision schedules must anticipate the significant period of time it takes for standards to sift through the policy system.

For example, even though each California subject-matter framework is scheduled for review only once every eight years, it takes about two years for publishers to respond to the new standards, and more time for tests to be developed and meaningful staff inservices to occur. As it stands, elementary teachers are faced with revising a new subject just about every year (Marsh and Odden 1991). Thus the revision schedules standards groups employ must balance the need to incorporate new knowledge with the concern that frequent revision can overwhelm the system.

\section{Conclusion}

This brief attempts to distill lessons from past curriculum 
reforms and from recent efforts of states, localities and associations to set standards for student learning. Several practical suggestions for the process of standard setting emerge. Standards efforts should:

- survey each content area, its domains and issues, in advance of setting standards;

- develop iterative processes for including professional and public participation;

- construct reasonable timetables for completion of standards;

- consider the use of multiple formats for various subject areas;

- develop activities to bridge disciplines;

- seek to remain flexible while developing standards that are specific enough to provide meaningful guidance;

- anticipate and address controversy; and

- support continued capacity building and plan for revision over time.

This list gives rise to two final thoughts about standards activities.

First, while a number of aspects of standard setting appear to require tradeoffs and compromises, ways can be found to achieve balance that avoid sacrificing one value on behalf of another. States, localities and associations have found ways, through back- and- forth consultation and review, to include both professionals and the public; most efforts have not found it necessary to give up professional leadership to achieve public support or to forgo broader understanding in order to create frameworks respected by both practitioners and scholars. Similarly frameworks can be constructed that are both specific and flexible; neither goal need be scrapped in behalf of the other.

Second, standards efforts clearly have purposes and raise issues that extend beyond the seemingly narrow function encompassed by a term like "framework development." Standards processes raise difficult values questions and must deal with the controversies they unleash; they must provide for public understanding and support long-term capacity-building for professionals. Whatever the structures and mechanisms that states, districts and associations use for standards development, they must accommodate these varied and continuing needs.

\section{References}

Ball, D. L. 1992. Implementing the NCTM Standards: Hopes and Hurdles. Issue paper 92-2. East Lansing, MI: National Center for Research on Teacher Learning.

Carlson, C. G. 1992. The Metamorphosis of Mathematics Education. Princeton, NJ: Educational Testing Service.

Cohen, D., and J. Spillane. 1993. "Policy and Practice: The Relations Between Governance and Instruction." In Designing Coherent Education Policy: Improving the System, ed. S. H. Fuhrman, 35-95. San Francisco: Jossey-Bass.

Darling-Hammond, L. 1992-93. "Creating Standards of Practice and Delivery for Learner-Centered Schools." Stanford Law and Policy Review 4 (Winter): 37-52.

Elmore, R. F. 1993. "The Development and Implementation of Large-Scale Curriculum Reforms." Paper written for the American Association for the Advancement of Science, Washington, DC.

Fuhrman, S. H. 1993. "The Politics of Coherence." In Designing Coherent Education Policy: Improving the System, ed. S. H. Fuhrman, 1-34. San Francisco: Jossey-Bass.

Fuhrman, S. H., and D. Massell. 1992. Issues and Strategies in Systemic Reform. New Brunswick, NJ: Rutgers University, Consortium for Policy Research in Education.

Marsh, D. D., and A. R. Odden. 1991. "Implementation of the California Mathematics and Science Curriculum Frameworks." In Education Policy
Implementation, ed. A. R. Odden, 219-240. Albany: SUNY.

Massell, D. 1993. "Achieving Consensus: Setting the Agenda for State Curriculum Reform." In Governing Curriculum, eds. R. Elmore and S. Fuhrman, Washington, DC: ASCD. Forthcoming.

Massell, D., M. Kirst, C. Kelly, and G. Yee. 1993. "Formulating Content Standards: Case Studies and Implications for National Content Standards." A report for the National Education Goals Panel, Washington, DC.

McLaughlin, M. W. 1991. "The Rand Change Agent Study: Ten Years Later." In Education Policy Implementation, ed. A. R. Odden, 143-155. Albany: SUNY Press.

O'Day, J., and M. S. Smith. 1993. "Systemic Reform and Educational Opportunity." In Designing Coherent Education Policy, ed. S. H. Fuhrman, 250-312. San Francisco: Jossey-Bass.

Pechman, E. M., and K. G. Laguarda. 1993. Status of New State Curriculum Frameworks, Standards, Assessments, and Monitoring Systems. Report prepared for the U.S. Department of Education. Washington, DC: Policy Studies Associates.

Pence, P., and A. Petrosky. 1992. "Defining Performance Standards and Developing an Assessment for Accomplished English Language Arts Teaching of Young Adolescents." Paper presented at the annual meeting of the National Council on Measurement in Education, April 21, 1992.

Porter, A. C. 1993. "Defining and Measuring Opportunity to Learn." Paper prepared for the National Governors' Association, Washington, DC.

Porter, A. C. 1993. "School Delivery Standards." Educational Researcher (June-July): 24-30.

Smith, M. S. and O'Day, J. 1991. "Systemic School Reform." In The Politics of Curriculum and Testing, eds, S. H. Fuhrman and B. Malen, 233-267. Philadelphia, PA: Falmer Press. 